\title{
Use of a Webpage in Designing Employee Data Collection at the Aceh Language Center Office
}

\section{Safrinal}

Institute of Information Technology, STMIK Indonesia

Email: safrinal@stmikiba.ac.id

\author{
Inyak Sukendi * \\ Institute of Information Technology, AMIK Indonesia \\ Email: inyak.sukendi@amikindonesia.ac.id
}

\section{Supriyanto}

Research Division, Jhonson Coorporation

Email: supriyanto@jhonsoninternational.com

\author{
Afrizal \\ Research Division, Lembaga KITA \\ Email: afrizal@lembagakita.org
}

Received: 30 January 2021; Accepted: 13 March 2021; Published: 1 April 2021

\begin{abstract}
The employee information system is one of the data processing activities at the Aceh Language Hall Office, to get information about employees to be more focused and easy to obtain. In this study, researchers only discussed employee problems and data management mechanisms at the Aceh Language Center Office and designed an employee data collection information system using PHP and MySQL. The research objective was to understand the problems of employees and data management at the Aceh Language Center Office and to create a supporting application about employee information systems using PHP and MySQL. The collection of data needed in writing this report was obtained by two methods, namely literature studies related to literature, library books, and other scientific works, field studies by conducting interviews, and direct observation of objects related to this research. The employee information system is carried out by one of the administrative staff and assisted by 2 (two) employee administration staff to record and input employee data. From the results of the study, it can be concluded that the employee information system at the Aceh Language Hall Office has followed the procedure and uses a computer with the PHP and MySQL language programs as the database.
\end{abstract}

Index Terms: Information Systems; Data Collection; Employees; PHP and MySQL.

\section{Introduction}

With the development of the times, changes and dynamics of society are getting faster [1]. Information technology is an example of a technology product that can help make it easier for humans to manage data and present quality, fast and accurate information [2,3]. Technology in the era of globalization also plays an important role in supporting daily activities, both in the world of education, business, entertainment, government, and so on [4, 5, 6], one of the technological developments is computers.

Employee data is one of the important things that need to be considered in a company [7, 8]. Almost all companies, ranging from small to large scale, have started using computers to support their operational activities both in collecting employee data and assisting in decision making. The Aceh Language Hall Office is one of the companies that use information technology used for employee data collection, but the management process has not been maximized because so far the Aceh Language Hall Office has only used regular office applications which resulted in delays in data collection and retrieval of employee data. From the description above, the aim of the research is to find out and design the use of a webpage in designing employee data collection applications at the Aceh Language Center Office. 


\section{Background and Analysis}

From the methods and steps taken at the running system analysis stage, in identifying existing problems, it is deemed necessary to carry out the system development process, namely by creating an employee data processing application using PHP and MySQL programs so that it is easy to understand, dynamic and allows users to integrate with the application, and have fast and accurate access to data processing. The system created offers advantages over existing systems, for example:

a) The system is easy to use by others.

b) The system will display information that is easy to use and understand because information related to the data processing of employees at the Aceh Language Hall Office plays an active role.

The main result of the analysis is a complete understanding of the system in preparation for the design stage as well as the implementation and testing stages. The system applied to the administration is still manual, namely by handwritten notes on the employee databook.

The data that is managed on the current system is not systematic, where the data that is owned cannot describe the data uniquely. Seeing the condition of the data processed by the current system, it is necessary to create a data coding system, so that some data of the same type can be recognized as the desired object. In the process of processing employee data at the Aceh Language Hall Office, a computerized system uses standard applications such as Microsoft Office Excel, but obstacles also often occur due to repeated data filling in determining data storage per day so that the process seems slow. And the process of making reports sometimes goes wrong and sometimes experiences delays in delivery to the parties concerned. Besides that, it also causes a waste of time and energy. There are still many shortcomings in the data creation process, namely:

a) The time needed is too long, starting from the process of entering employee information data from the department to making employee reports

b) Arrangement of employees is sometimes done using the Excel application which results in difficulty finding files within a certain time

c) Insufficient data security because the storage media used is easily damaged and easily accessible by many people.

The ongoing analysis procedure describes systematically the activities that occur in the employee information system at the Aceh Language Hall Office, the ongoing employee data processing procedure:

a) Employee data is recorded on a simple employee book

b) Furthermore, the employees are recorded and recorded in the excel application

c) Each data is separated from employee data according to the position.

d) The leadership verifies employees every month.

e) Employee information reports are submitted and reviewed by the Management at the end of each year

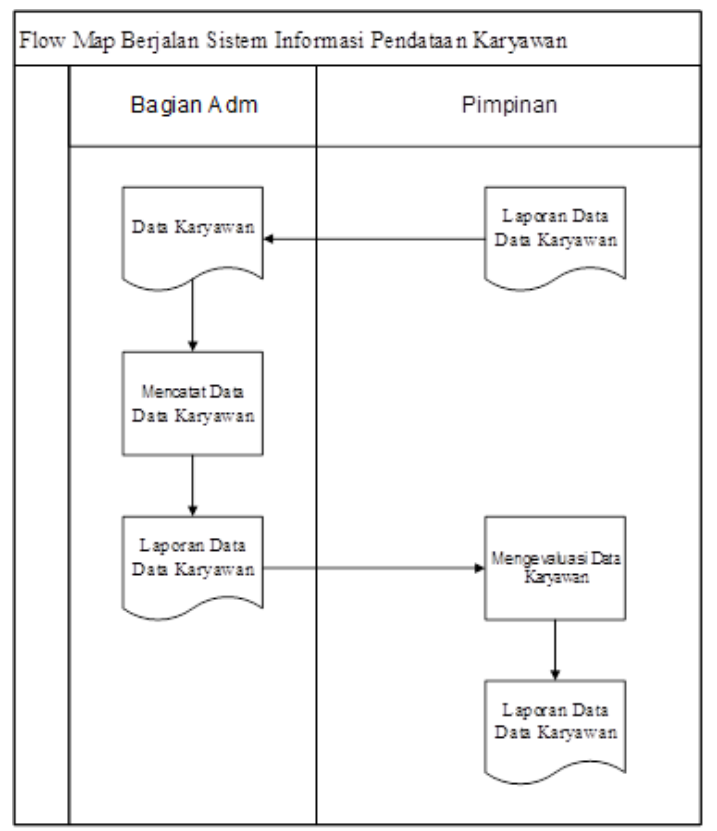

Fig.1. FlowMap System 
Judging from the system that is currently running at the Aceh Language Hall Office, the authors draw the conclusion that the current system is still considered ineffective for the Aceh Language Hall Office in terms of the employee data collection process, recording data in employee books, and re-recording it in the Microsoft Office Excel application. For that, we need a solution as an alternative to overcome these problems, one of which is by implementing a web-based application to support web-based employee data collection.

\section{Result Analysis and Discussion}

System design is an ongoing system and process development activity to produce a new system or update an existing system to increase work effectiveness in order to meet the results used with the aim of utilizing available technology and facilities. In this chapter, the writer will give an indication which is computerized system information that is expected to help and simplify the work.

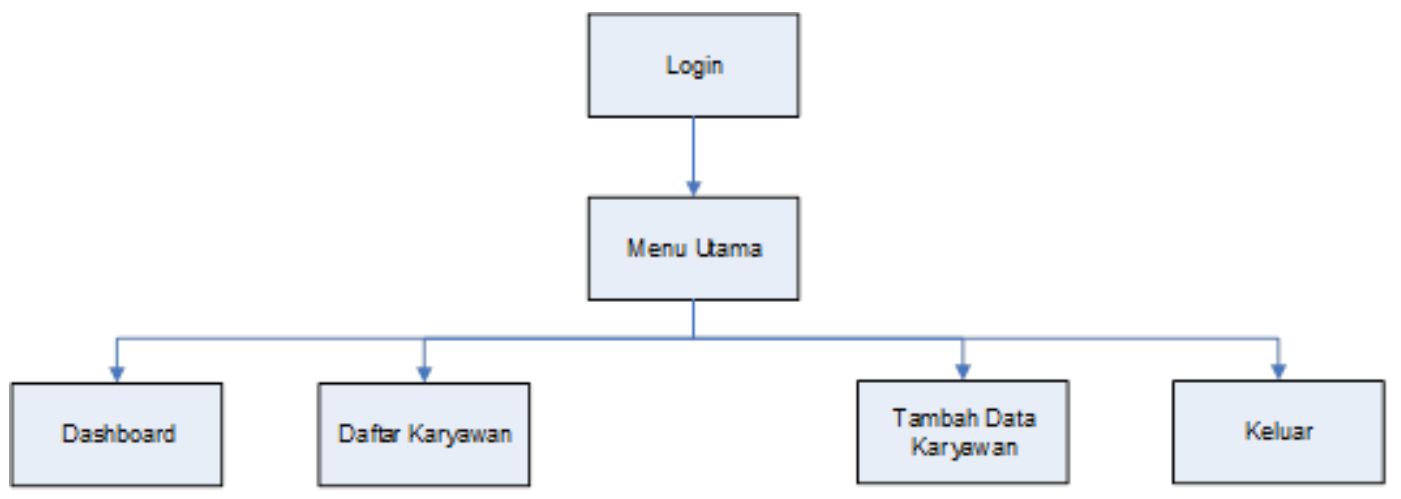

Fig.2. Program Menu Structure

In fact, the employee data collection process at the Aceh Language Center Office has been using computers. employee data collection, then the administration section to fill in new employees to fill in other completeness data. Furthermore, after all the data is complete, the tax department makes a recapitulation report regarding the employee's data. To be clearer, the financial data collection system can be seen in the login flowchart, main menu flowchart, employee data input flowchart, employee data search flowchart, and flowchart as the following employee data recap reports.

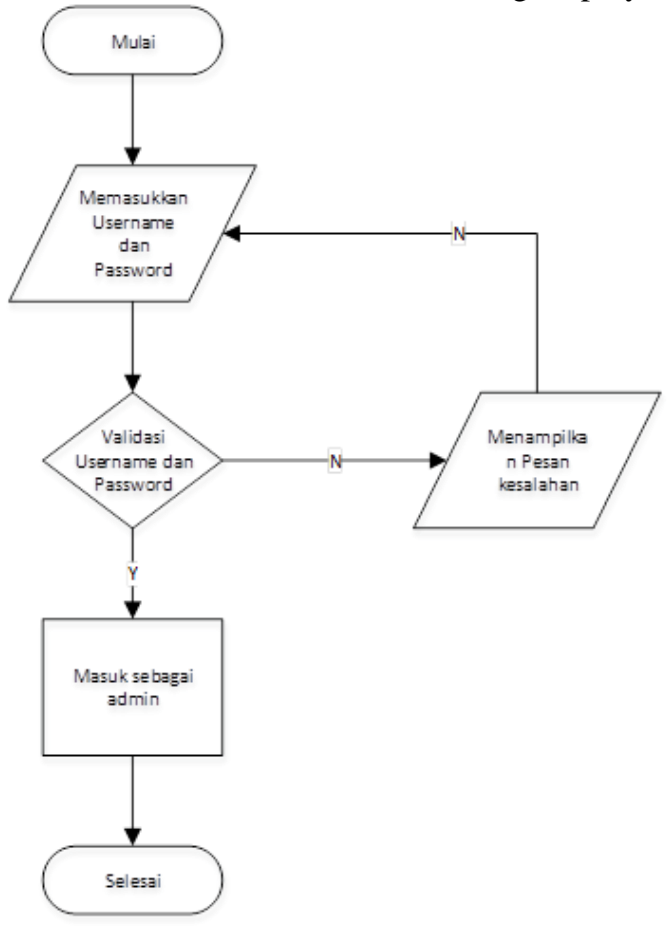

Fig.3. Login Flowchart 


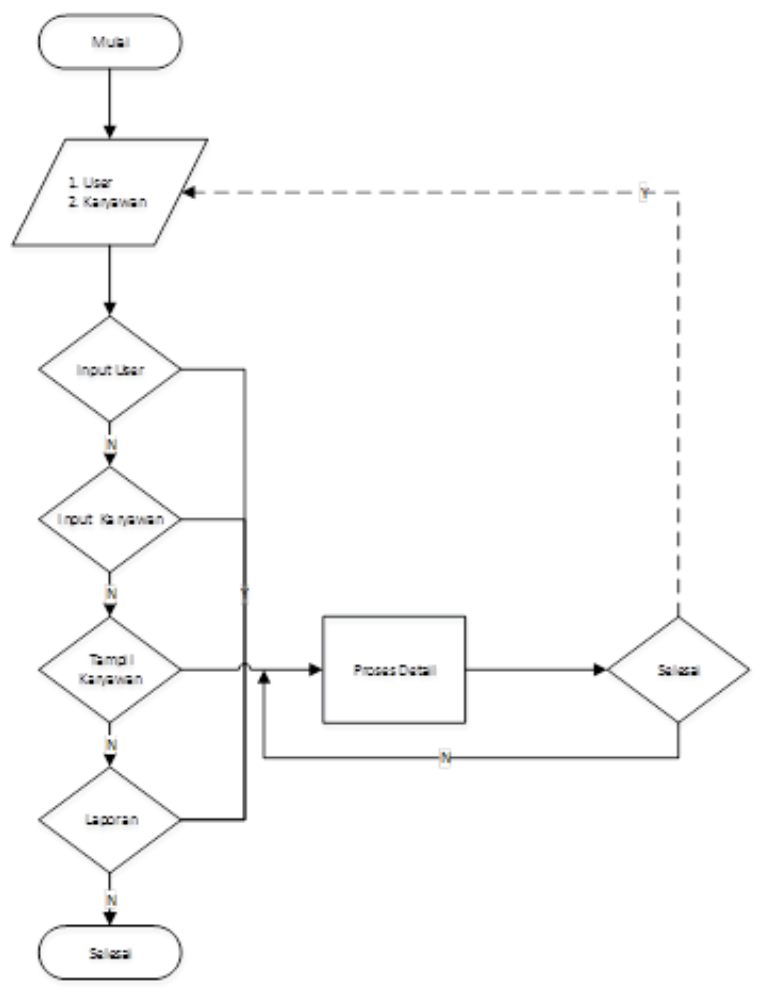

Fig.4. Main Menu Flowchart

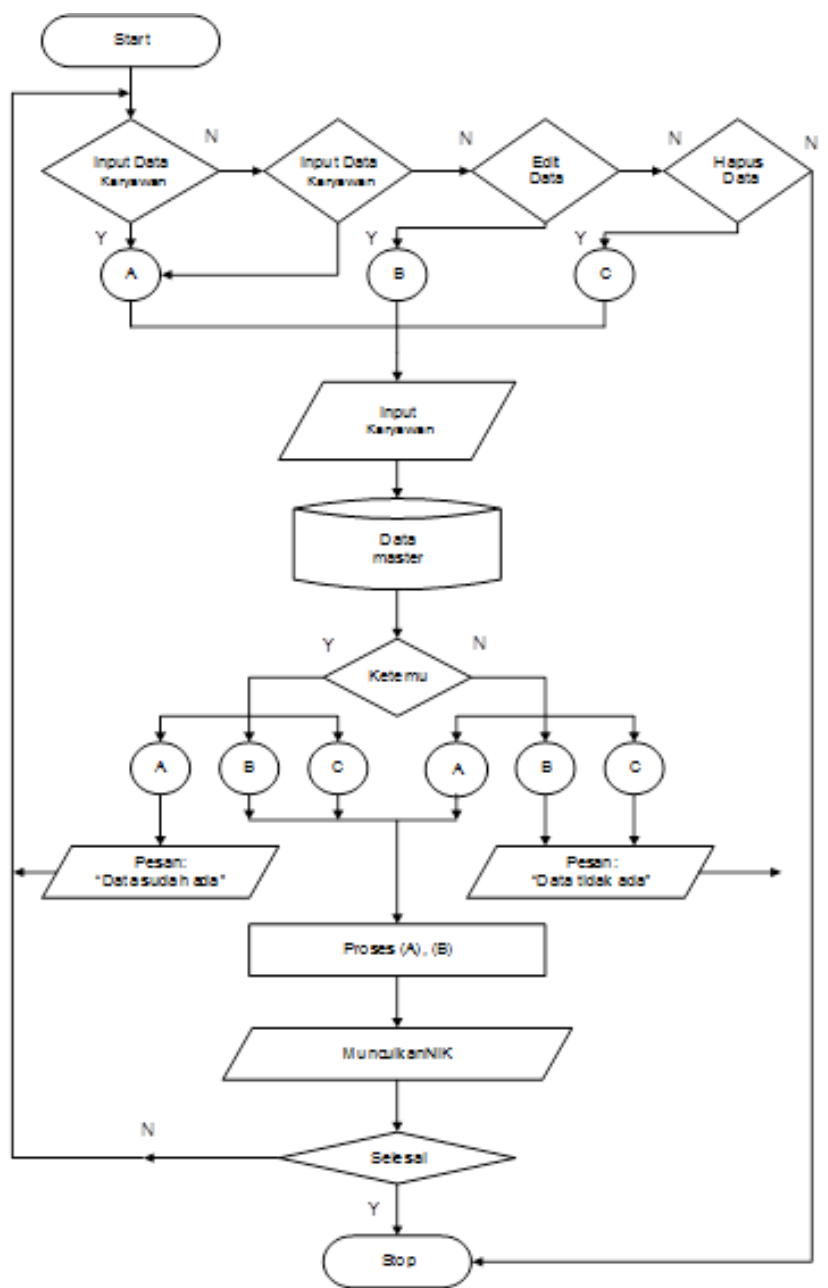

Fig.5. Employee Data Input Flowchart 
Hasil dari penelitian ini menghasilkan sebuah aplikasi pendataan karyawan seperti pada gambar 6 berikut

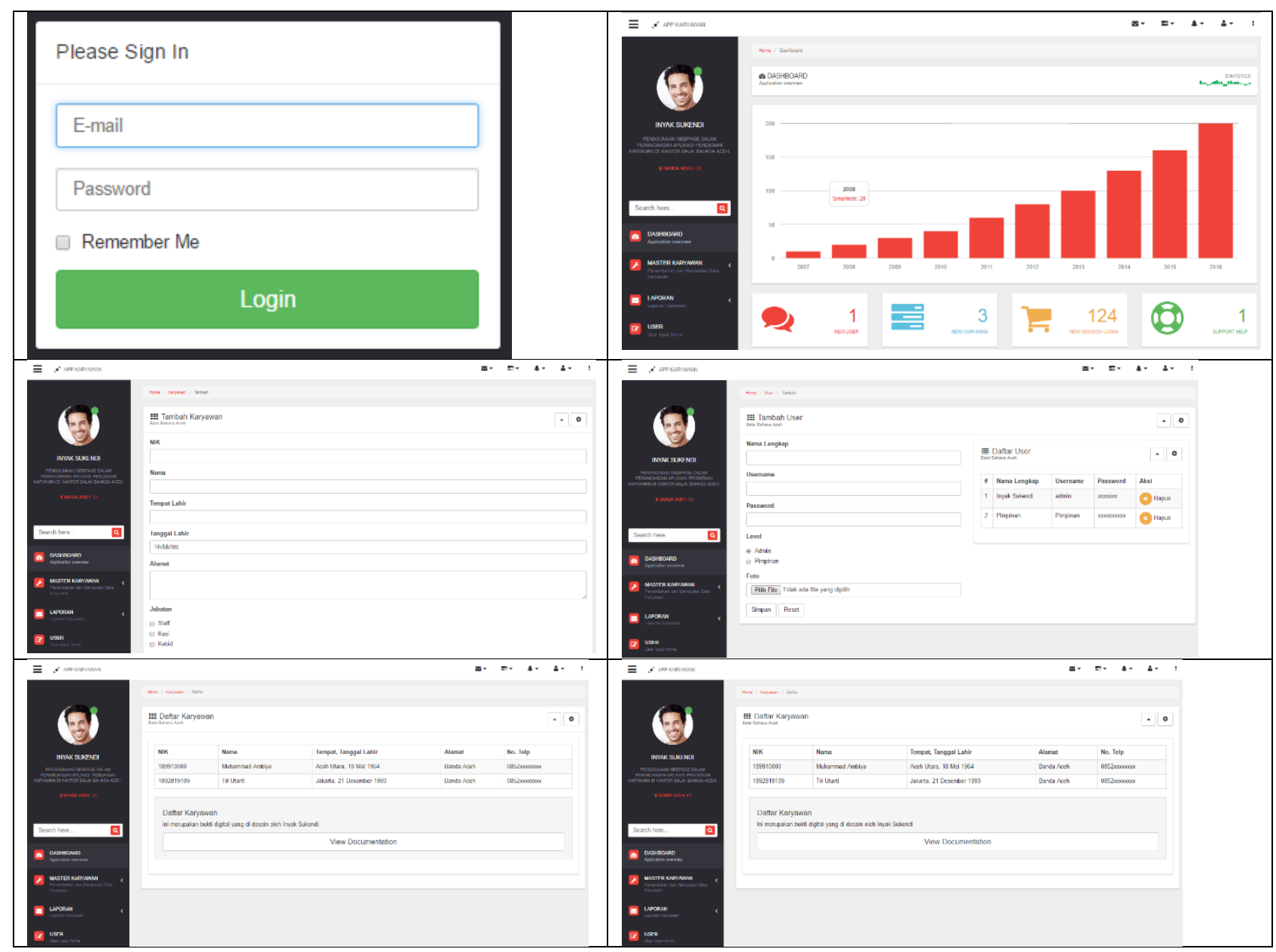

Fig.6. Application Results

The display shows the order from the left side to the bottom showing from the login form, the application main menu, the search employee data input form, until the report has been provided by the application with the aim of improving data management and employee data management better and the application is developed with web technology so that can assist companies in managing employee data online.

\section{Related Work}

Previous research has been carried out by several researchers, the application of employee data collection is expected to be a medium for delivering useful and useful information to improve the quality of the company as well as the competitive value for the company, especially employees / female staff at service companies [9]. Website-based employee data collection application to facilitate companies in recording employee data, storing employee data, searching employee data, and information on all employee data. With this new system, it is hoped that it can help the admin or related departments in recording employee data, storing employee data, searching for employee data, and making it easier for the related department to get all the information about employees [10]. The design of data applications with the presentation of this employee data information system as an application interface that is designed has become an alternative solution in the delivery of employee reports, employee biodata, and employee positions at a university that is more efficient, so as to reduce the possibility of errors that occur. Information systems provide benefits for admins or officers in processing salaries using computer software. Produce a payroll application that can make it easier to process employee data [11]. Seeing previous research that management data management is an important point in human resource data management in an organization, this study focuses on the needs of the research object as well as the needs of each specific period report. 


\section{Conclusion}

Based on the results of observations and the author can draw a conclusion which includes the following:

a) The use of employee data processing is good enough and using computers as a data processing tool, although data processing still relies on Microsoft Office, making it difficult to produce accurate and effective reports.

b) The existence of an information system makes it easy for offices to evaluate companies and this application, it can solve problems that exist at the Aceh Language Hall Office because it speeds up manufacturing and reduces errors.

c) Produced an employee information system to support employee monitoring at the Aceh Language Center Office.

\section{Acknowledgment}

This research was partially supported by The STMIK Indonesia, Banda Aceh City under the AMIK Indonesia Teacher Research Grant, and the Jhonson Corporation Research Team with the KITA Indonesia Institute.

\section{References}

[1] Amri, Khairul, and Jen Surya. "Kajian perilaku mahasiswa dalam menggunakan internet dengan pendekatan technology acceptance model (TAM)." Jurnal Penelitian Pos dan Informatika 3.1 (2013): 67-80.

[2] Wali, Muhammad, and Lukman Ahmad. "Source Code Library (SCL): Application Support Learning Software Development: Source Code Library (SCL): Application Support Learning Software Development." Jurnal Mantik 4.1 (2020): 7-13.

[3] Rizal, Syamsul, and Badaruddin Badaruddin. "PENGARUH PENERAPAN MANAJEMEN KINERJA DAN PENGEMBANGAN KARIR TERHADAP KINERJA KARYAWAN PT. TELKOM KANDATEL ACEH." JEMSI (Jurnal Ekonomi, Manajemen, dan Akuntansi) 3.2 (2017): 31-39.

[4] Ahmad, Lukman, et al. "IbM Pemberdayaan Generasi Muda melalui Enterpreneurship." Jurnal Pengabdian Nasional (JPN) Indonesia 1.1 (2020): 30-36.

[5] Tarmizi, Tarmizi, and Ismail Ismail. "Model Marketplace Berbasis Kearifan Lokal." Jurnal EMT KITA 4.1 (2020): 11-18.

[6] Ihsanuddin, Ihsanuddin, Abdus Salam, and Fauzan Putraga Al Bahri. "Mapping Halal Tourism Model as an Effort to Increase Visitation at Banda Aceh." Jurnal EMT KITA 3.1 (2019): 42-46.

[7] Kristanto, Harris. "Keadilan organisasional, komitmen organisasional, dan kinerja karyawan." Jurnal Manajemen dan Kewirausahaan 17.1 (2015): 86-98.

[8] Jatmiko, Enggar Dwi. "Pengaruh Motivasi Kerja Dan Komitmen Organisasional Terhadap Kinerja Karyawan (Studi Pada Karyawan Kompartemen Pabrik II PT. Petrokimia Gresik)." Jurnal Administrasi Bisnis 21.1 (2015).

[9] Harfizar, et al. "Perancangan Sistem Informasi Pendataan Karyawan Pada Perusahaan Jasa Berbasis WEB." Journal Sensi 3.2 (2017): 190-207.

[10] Irawan, Yogi. LKP: Sistem Aplikasi Pendataan Karyawan pada PT. Hanil Jaya Steel. Diss. Institut Bisnis dan Informatika Stikom Surabaya, 2017.

[11] Tri, Haryanto. SISTEM INFORMASI DATA KARYAWAN DI UNIVERSITAS WIDYA DHARMA KLATEN. Diss. Universitas Widya Dharma, 2019. 